\title{
A Review on Utilization Routes of the Leather Industry Biomass
}

\author{
Million Ayele $(\mathbb{D}$, Derseh Yilie Limeneh, Tamrat Tesfaye, Wassie Mengie, Amare Abuhay, \\ Adane Haile, and Gemeda Gebino
}

Ethiopian Institute of Textile and Fashion Technology, Bahir Dar University, Bahir Dar, Ethiopia

Correspondence should be addressed to Million Ayele; milliti2000@gmail.com

Received 17 September 2021; Revised 29 October 2021; Accepted 22 November 2021; Published 21 December 2021

Academic Editor: Carlo Santulli

Copyright ( $) 2021$ Million Ayele et al. This is an open access article distributed under the Creative Commons Attribution License, which permits unrestricted use, distribution, and reproduction in any medium, provided the original work is properly cited.

\begin{abstract}
The use of biomass to produce bioenergy and biomaterials is considered a sustainable alternative to depleting fossil fuel resources. The world tanneries consume 8-9 MT of skin and hide every year producing 1.4 MT of solid waste. Most of the solid biomass generated from tanneries is disposed of as waste in the environment using either landfilling or thermal incineration. Disposal of this waste into the environment affects the ecosystem, causing bad odor (air pollution) and has an antagonistic impact on the environment. Due to this, European Union legislation bans the landfilling of biomass. This study aims to comprehensively review the possible valorization routes of leather processing industry biomass into high-value biomaterials. Leather biomass (trimmings, shaving, splitting, and buffing dust) mainly contain $30 \%-35 \%$ collagen protein, which is produced by acid or alkali hydrolysis. The biopolymers obtained from leather industry biomass can be utilized in the production of several high-value materials. In addition, leather processing industry biomass also contains fat, which can be converted into a bio-surfactant, and other useful biomaterials. Keratin protein can also be extracted from the hair waste of hides and skins. The increased demand for biomaterials makes the using of leather industry biomass very attractive. From this study, it can be concluded that the conversions of leather processing industry waste to valuable biomaterial can protect the environment, generate additional income for leather industries, and pave way for sustainable and renewable biomaterials production.
\end{abstract}

\section{Introduction}

Biomass is the renewable resource that constitutes the foundation for bioeconomy development. Biomass features as sustainable supply, extensive availability, easy accessibility, and production potential which make this renewable biomass a unique material source for the production of bioenergy, bio-fuels, and bioproducts. The society is currently facing a series of environmental and social challenges such as the growth of world population, climate change, and degradation of ecosystems that require the definition of new production and consumption pathways that are sustainable from the economic, social, and environmental point of view [1].

Presently, attention has been given to the conversion of biomass to bioenergy and biomaterial due to the significant benefits they offer in many aspects. As a result, there is a need for the total transformation of the entire economy from fossil-based to bio-based production and consumption. The conversion of biomass to biomaterial and bio-energy is accomplished by the biorefinery approach [2]. The strategy of biorefining has been recognized as the main element to boost the emerging bioeconomy by offering a wide range of products from a wide range of biomass sources to satisfy the diverse demands of the community. "In addition, biorefineries are key elements to support the development of a circular bioeconomy by connecting the stream and loops and allowing for the valorization of multiple side-products" $[1,3]$.

Leather industries are among the industries that generate plenty of proteinase biomass. The solid biomass such as hair, trimmings, flashing, splitting, and shaving are the potential starting materials for the production of high-value biomaterial. Presently, solid biofuel is in use in Europe; however, it does not achieve the quality of black coal [4].

The need for meat in the world is increasing as the population growth increases and remains growing and high in the economic development. Hence, livestock and meat are 
essential parts of global economic development. The increased need for meat generates huge amounts of skin and hides, which are raw materials for tanneries. During the processing of this skin and hide, a huge amount of waste is generated, which has an antagonistic impact on the environment [5].

The residues generated during leather processing are fleshing, chrome shaving, trimmings, hair, and pieces of cuttings [6]. $1000 \mathrm{~kg}$ of raw hide generates $800-850 \mathrm{~kg}(80 \%-$ $85 \%)$ of solid wastes in leather processing, of which $56-60 \%$ is flashing waste; $35-40 \%$ is chrome shaving, split, and buffing waste; $5.7 \%$ is trimmings; and $2.5 \%$ is hair $[7,8]$. Animal hide and skin consist of different layers like the dermis, epidermis, and subcutis. Subcutis is the lower layer or under the skin of the hide or skin mostly scraped as a biomass in leather processing, which is rich in collagen protein [9].

The leather biomass, particularly trimming, fleshing, and shaving are sources of protein (Collagen/gelatin). The leather biomass disposed of contains 30-35\% collagen, it also contains keratin and fat [10]. The valorization of these waste results in the production of sustainable, biodegradable, and eco-friendly high-value bioproducts and replacement for petroleum-based materials.

In addition, utilization of these biomass integrates bioeconomy by circulating in the value chain of the circular economy. The circular economy has been given great attention with a high-level strategy within the European Union that benefits the society beyond the current level. "Biomass is highly significant in a circular economy in terms of material products and the provision of energy. To establish a circular bioeconomy, the practical implications of biomass use need to be appreciated by stakeholders throughout the value chain, from product design to waste management" $[11,12]$.

Many scholars investigated the valorization of proteincontaining nontannery biomass to different biomaterials. However, very few scholars have shown the possible conversion of tannery biomass to biomaterial. There are no comprehensive reviews so far done on the valorizations of tannery biomass to the high-value biomaterial. Therefore, in-depth research is required to maximize the utilization of leather biomass. Furthermore, the application of biosurfactants obtained from tannery biomass such as wetting agents, softener, lubricant, and detergent in textile wet processing was not studied so far. In the current work, a comprehensive review on the possible utilization of leather biomass for biomaterials and bioenergy, and their application in different areas of science and technology was assessed. The study can also provide possible research areas for future work. Leather industry biomass like fleshing, trimmings, shaving, and splitting can be the main sources of collagen, which could then be converted to gelatin after chemical/physical reaction. This results in the production of sustainable, cost-effective, biodegradable, and ecofriendly high-value material from collagen/gelatin. In addition, the fat extracted from the waste is used as a building block in biosurfactant production and other bioenergy manufacturing. Besides, it will be essential to identify the current and future market needs to combine biomass demand and supply and the sustainability of cohesive biomass production and supply chains systems to secure a reasonable bio-based economy development.

1.1. The Leather Industry. The need for meat in the world is increasing as the population growth increases and remains growing and high in economic development. Hence, livestock and meat are essential parts of global economic development. The production of skin and hide in the world is estimated to be 8-9 MT per annum [7]. Presently, the world's major leather manufacturers are located in Asia; China is the leader, followed by India and Hong Kong. Among European countries, Italy is the leader in this sector, followed by France [13]. Processing skins and hide into finished leather generates $1.4 \mathrm{MT}$ of waste containing mainly protein. This may cause an antagonistic impact on environmental pollution unless it is managed properly. Tanning contains large quantities of water as well as inorganic and organic chemicals. The leather production procedure and waste disposal are summarized in Figure 1. This practice leads to the production of both functional and ineffectual biomass. Fleshing and shaving wastes are major components of biomass, whereas hair wastes are the major source of fertilizer [7].

\section{Disposal Techniques of Leather Biomass}

Due to the movement of people from rural areas to cities and towns, urbanization in the world is increasing, which raises the human population in urban areas. As a result, industrialization around the urban areas increase leading to the disposal of huge amounts of waste to the environment [14]. To improve waste management, first of all, the following steps should be always considered to get the best approach (Figure 2).

Hides and skins are the biomass of slaughtering activities that can be converted into various end products. For every end product, the process of tanning is different and the amount and type of waste obtained may vary to a great extent. In the production of leather, a high percentage of raw materials are rejected as solid waste. In addition, the processes carried out at different stages have a significant environmental impact [15].

2.1. Landfill. In leather production, only $15-20 \%$ of the total mass of the raw skin or hide is changed to final finished leather products. The precise proportion varies depending on the animal classes and product requirements being produced. $80-85 \%$ of the skins and hides of solid wastes are disposed of as landfills which have a great impact on the environment and health [16]. For many years, landfilling has been the most used disposal method chosen by tanneries. However, this option is not the best method because of its environmental impact and the increasing contamination of groundwater and soil [17]. Due to this, European Union legislation bans landfilling of biomass in developed countries [18]. In addition, unutilized portion of the chemical process is disposed of in the wastewater. 


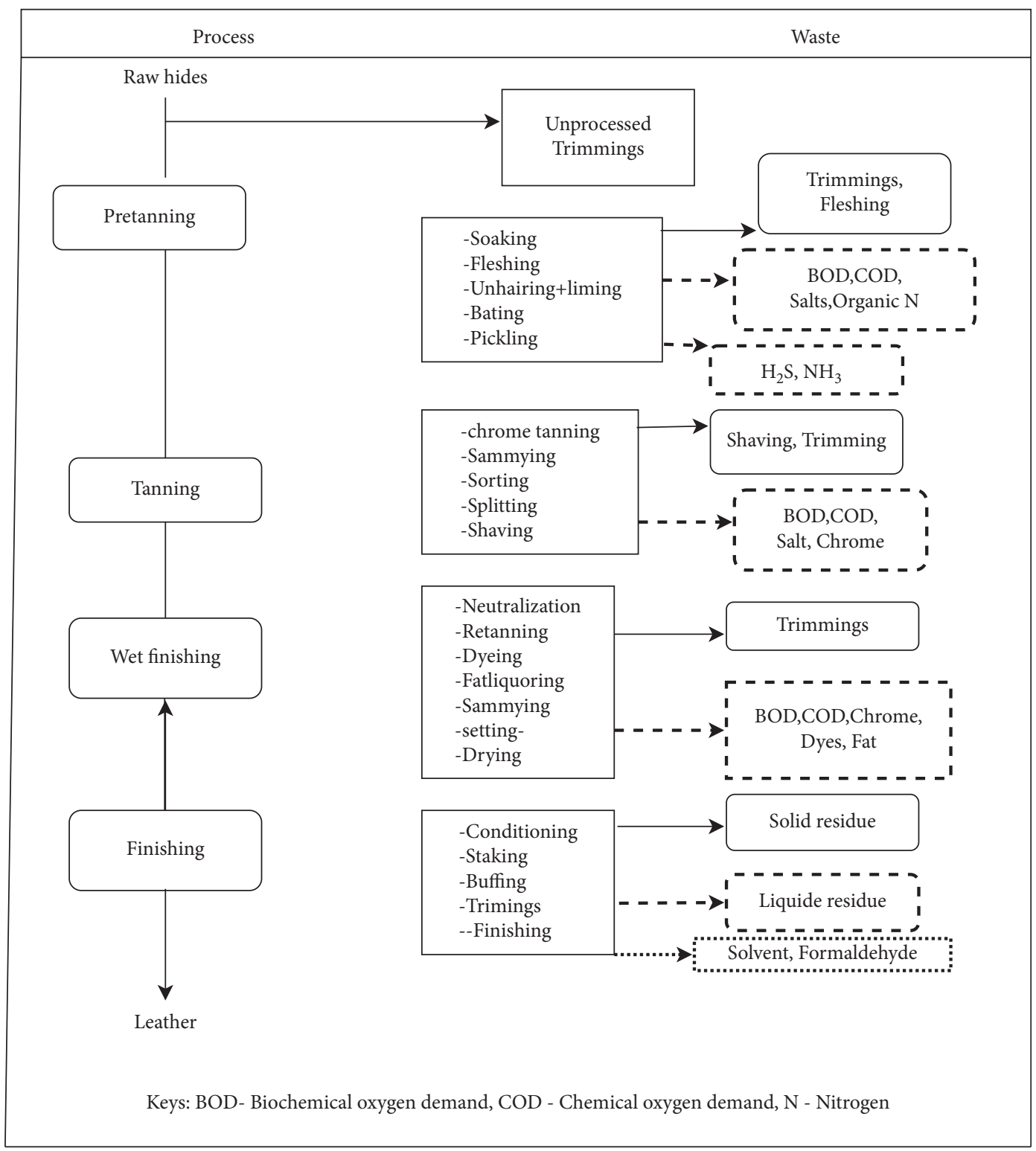

\footnotetext{
— Solid waste

- - - Liquid waste

..... gaseous waste
}

Figure 1: Description of the tanning process and waste disposal (adopted from [7]).

Consequently, the concern is that, if the present solid waste removal methods continue, the waste has to be transported to a long distance, which will cost much for transport facilities and infrastructure. Landfilling scenario requires the highest transportation cost, and also sites available for landfills are quickly occupied, and getting new sites would become difficult. Indiscriminate landfilling leads to contamination of water quality in the areas surrounding the landfill sites due to pollution by landfill leachates.

In addition, landfill gas, which generates $50-60 \%$ methane, contributes to global warming significantly [19]. Hence, environmental scientists have discouraged landfill methods of disposal and new technological interventions were made. Less attention has been given to the leather industry's solid waste management, and it is common to observe lots of waste dumped illegally around tannery compounds, rivers, and other open places [16]. "Therefore, to avoid any possible consequences due to the degradative effects of these materials arising from their landfilling, researchers from all over the world are studying safer waste disposal methods to recover and reuse these wastes in other various industrial applications" [17].

2.2. Thermal Incineration. Thermal incineration is a technology of thermal destruction, which is one of the most efficient methods for killing conceivably contagious agents. Tannery wastes such as sludge, shavings, and buffing dust 


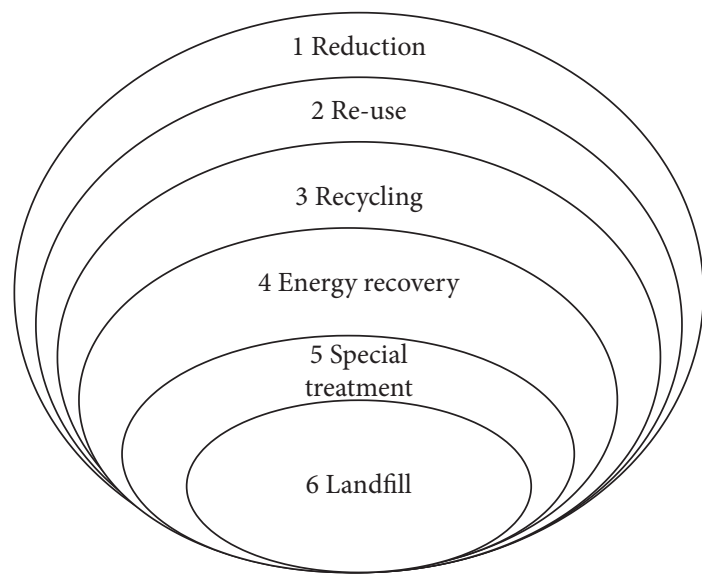

FIgURE 2: Steps to improve the management of waste.

can be thermally treated to reduce the volume of waste to be disposed of [19]. This method of waste disposal is the gasification and pyrolysis process, which generates energy. However, thermal incineration is an expensive option, but a suitable method for its instantaneous energy production and capacity reduction of solid waste [20].

\section{Utilization of Leather Biomass: Current Uses}

The biomass generated from tanneries can be used for various purposes such as animal feed, glue, soil conditioner, fertilizer, decorative purposes, and fashion accessories. The organic biomass used for such purposes are fleshing, trimming; shaving, and splitting that are mostly obtained from raw skin/hide and semi-processed leather. Most of the industries disposed of the waste as landfilling; however, some of them are trying to recycle it to a useable form [21].

3.1. Leather Waste for Decorative Purposes. Leather trimmings/scraps and sheets, which have magnificent elongation and strength, can be used for various decorative applications. In addition, a composite sheet made of leather scrap can be used for various purposes in consumer applications, like inner decoration, clothing, bookbinding, leather wallpaper, furniture covering, wall coverage, key holder, and wallet. The desires for the determination of leather waste for decorative purposes are their protecting shape and size [22]. The following topics are some of the applications of leather biomass currently exercised.

3.2. Leather Biomass for Fertilizer Production. Fertilizers are compounds given to the plants to grow them and applied via soil to be up taken by plant roots or by foliar spraying. Leather biomass are used for the production of fertilizers (for soil conditioning) due to their richness in nitrogen $(\mathrm{N})$ content. However, the chromium part must be removed from the wet blue before conversion into fertilizer [23]. The leather fertilizer comprising an average amount of $140 \mathrm{~g} \cdot \mathrm{kg}^{-1}$ of nitrogen (dry weight), was rinsed three times and immersed in phosphorous (P) and/or potassium (K) salt solutions to produce $\mathrm{N}_{\text {leather }} \mathrm{PK}$ formulations. This mixture was agitated for $30 \mathrm{~min}$ and dried in a forced-air oven for $12 \mathrm{~h}$ at $70^{\circ} \mathrm{C}$. Potassium chloride and $\mathrm{KH}_{2} \mathrm{PO}_{4}$ salts were used in this process. The formulations were then crushed and selected according to grain-size analyses: $1.68-0.59 \mathrm{~mm}$. The salt amounts added to the collagen for the $\mathrm{N}_{\text {leather }} \mathrm{PK}$ formulations were based on the plant needs and the recommendations for fertilization in greenhouses [24]. Figure 3 shows a pathway (i) illustrating separation of chromium and collagen by extraction and the preparation of the material enriched with $\mathrm{K}$ and $\mathrm{P}$, pathway (ii) fertilizer synthesis process. The use of these wastes for soil conditioning/fertilizer is one of the alternatives to reduce waste disposal [23].

3.3. Leather Biomass for Animal Feed. Leather scraps, like splitting and trimming associated with the production of various leather processing can be collected and hydrolyzed similarly to poultry feathers. As shown in Figure 4, the biomass of this process is usually solvent extracted, dried, and ground into a meal for animals and chicken. Besides this, it is also used as a supplemental protein source since leather biomass is rich in protein content [25].

3.4. Leather Biomass for Glue. Traditionally sizing agents and adhesives were produced from animal skin and hides before thousands of years. During the production process of finished leather, the waste containing protein, fat, and tissue are generated at different stages. The solid biomass obtained from the leather production process contains $40-60 \mathrm{~g} \cdot \mathrm{kg}^{-1}$ of protein that is responsible for the preparation of glue [26]. The glue made from animal biomass is currently used for various applications, such as binding of books and catalogue, abrasive industry, paper production, emulsifying agent, metal and ore refining, emulsion stabilizer, and many other applications. In addition, it is also used as gesso and a mixture of whiting and glue [27].

The production process of animal glue starts with the cleaning of animal hides, tissue, and bones to avoid contamination. The tissue of the animal is soaked in water to start softening it and at this stage, the protein releasing process starts. Soaked tissue is then treated with acid and lime to assist the breakdown of tissue releasing more collagen. The acid is then avoided, and the water and collagen mixture are cooked to produce a thick, gelatin-like material. Then, it is purified and treated with chemicals according to the end use (Figure 5) [26].

3.5. Leather Biomass for Fashion Accessories. Materials that normally end up in the landfill are the starting point of any design process. These days, trimmings from finished leather biomass are fashionably converted into valuable products. Fashion accessories, like leather scarves, can be produced by applying the soften processes to trimmings [29].

\section{Physicochemical Properties of Leather Biomass}

Studying the physicochemical properties of a leather biomass is a vital step to identify the characteristics of a leather biomass that can be converted to valuable bio-material [30]. 
(i)

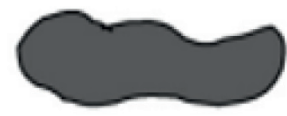

Wet Blue Leather $\left(\sim 30,000 \mathrm{mg} \mathrm{kg}^{-1} \mathrm{Cr}\right)$
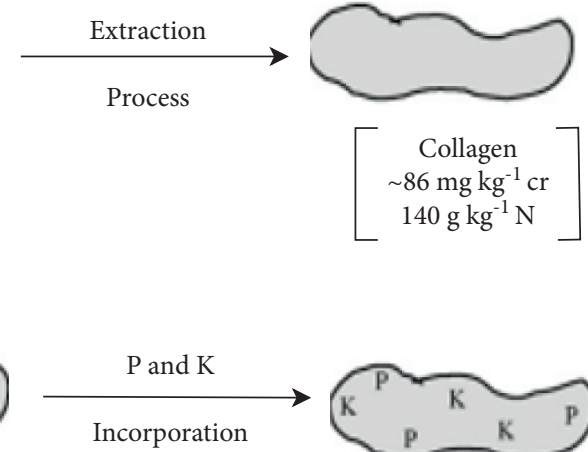

Collagen

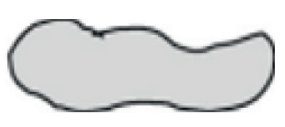

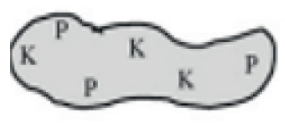

$\mathrm{N}_{\text {collagen }} \mathrm{PK}$

(New type of fertilizer)

Figure 3: Pathway (a) illustrating separation of chromium and collagen by extraction and the preparation of the material enriched with $\mathrm{K}$ and $\mathrm{P}$ pathway and (b) fertilizer synthesis process [23].

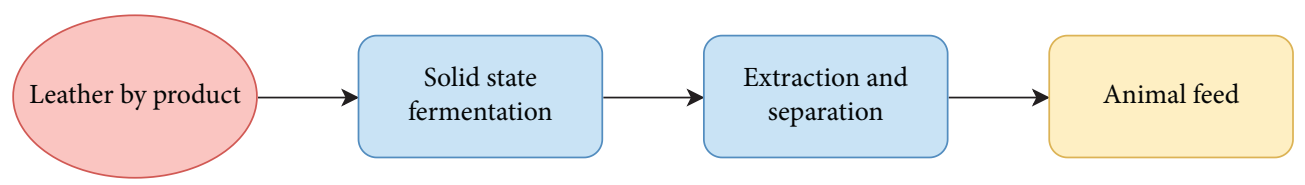

Figure 4: Animal feed production process from leather biomass.

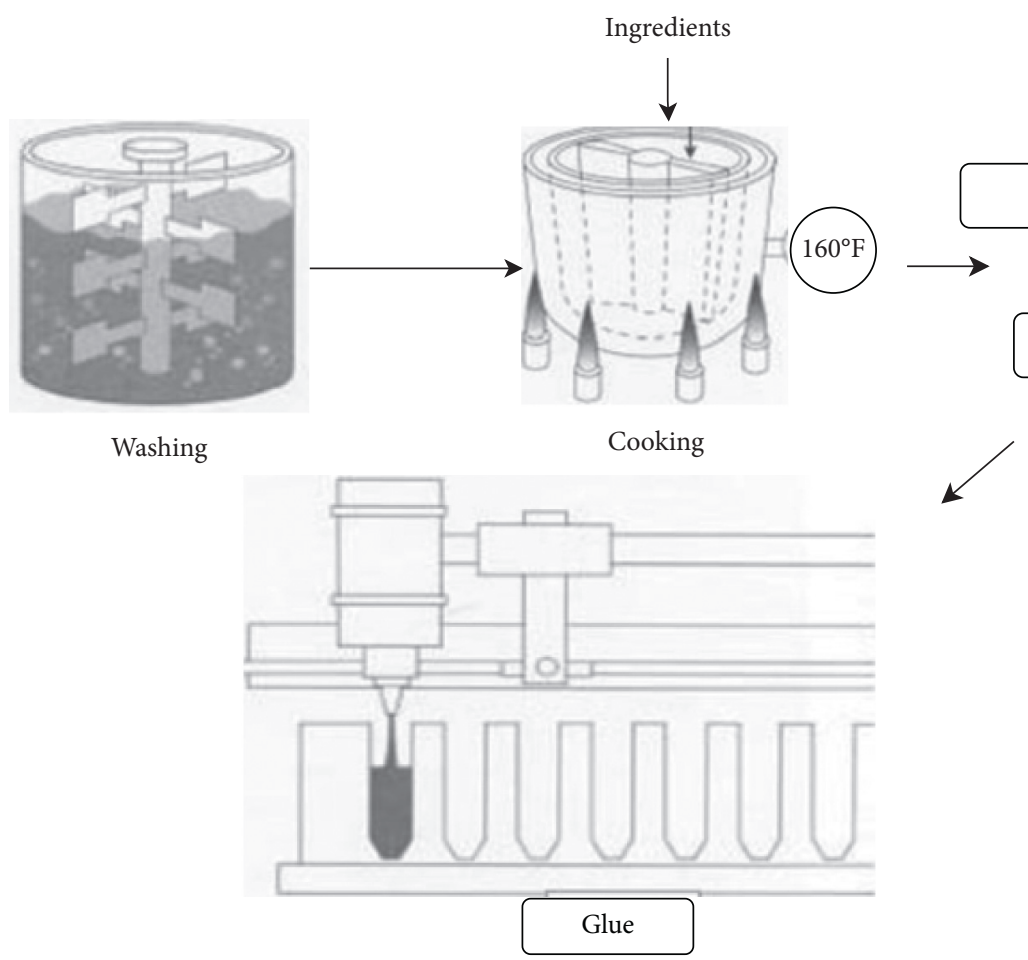

Figure 5: Production of glue from leather biomass (adopted from [28]).

A comprehensive description of leather biomass and their physical and chemical properties are explained in the next section.

4.1. Physical Properties of Leather Waste. The physical properties of leather make leather a unique and valuable material for upholstery purposes [31]. Leather biomass has high density than any other natural or engineered fabrics commercially available today. Besides the special structure and properties, leather biomass is very cheap, accessible, and a wanted type of product. The biomass is generally classified into solid and liquid biomass and the solid biomass comprise flushing, shaving, splitting, and hair. 
The total fresh hides and skins production of slaughterhouses is estimated to be 8-9 MT per year generating 1.4 MT of solid waste from tanneries [32]. In the processing of $1 \mathrm{MT}$ of skin and hide, about $600 \mathrm{~kg}-800 \mathrm{~kg}$ of solid biomass are generated as given in Table 1 [34].

4.2. Chemical Properties of Leather Waste. The chemical composition of raw untreated skin or hide biomass can be determined mainly by quality, sort of treatment type, and raw material. It contains protein as a major component. High moisture content (up to $80 \%$ ) is the property of leather materials. The amount of protein and fat is comparatively high and constitutes up to $10.5 \%(\mathrm{w} / \mathrm{w})$ and 2.5 to $10.5 \%(\mathrm{w} /$ $\mathrm{w})$, respectively, and $2-6 \%(\mathrm{w} / \mathrm{w})$ of mineral matters [8]. Table 2 shows the typical chemical compositions of skin and hide.

\section{Utilization of Leather Biomass: Prospects}

The productions of fresh skins and hides in the world are estimated to be 8-9 MT per year generating 1.4 MT of solid biomass [32]. Leather processing industries (tanneries) produce an enormous amount of solid biomass. The solid waste is categorized as fleshing waste (50-60\%), chrome splits, chrome shaving, buffing dust (35-40\%), skin trimmings (5-7\%), and hair (2-5\%) [36]. The biomass generated from tanneries has a very bad odor. The rapid growth of the population in the world is creating many tanneries that generate more solid waste, which exerts pressure on environmental conservation. Proper disposal of the biomass generated from the tanneries and protection of the environment and society is the responsibility of the industries. The disposal techniques currently available for leather solid biomass are landfill and thermal incineration, besides recycling of some of the biomass for decorative purposes and fashion accessories (trimming wastes), animal feed, fertilizer, and glue making [37]. Since the quantity of the waste disposed is large, there is a limitation in space for disposal and the disposal cost incurs extra expenses to the industries. Therefore, to sustain the production process of leather, there must be a mechanism that can convert these leather biomasses to high-value materials that can be used for different applications.

Many scholars investigated the utilization of solid leather waste for various uses. Due to its fertility in protein content, sustainable supply, plenty of availability, and cheapness, leather biomass is a potential starting material for biomaterials production. Figure 6 shows the proteinases material obtained from leather waste. Animal hide and skin contain proteins (90-95\% of solids, $35 \%$ by wt.), carbohydrates, lipids, water, and mineral salts. From many types of proteins, collagen exists in the largest quantity and is accountable for the creation of leather by combining with tanning agents. About $60 \%$ of hides and skins are proteinase material [38].

\subsection{Application of Collagen/Gelatin Obtained from Leather} Waste. Collagen is the furthermost commonly occurring protein class in both animals and humans. It is primarily made of glycine amino acid (33\%), hydroxyproline, and proline $(22 \%)$ (Primary structure), which is twisted by the three $\alpha$ - chains in a triplex helix. 1014 amino acids are available in every $\alpha$ - chain with $100 \mathrm{kDa}$ approximate molecular weight. The natural collagen can be synthesized from many sources like bovine and leather waste (trimmings, shaving, fleshing splitting, and buffing). Animal sources like lung tissue, bones, tendons, and connective tissue are other sources of collagen [39]. Furthermore, along with cellulose and lignin, it is one of the three dominant biopolymers. Collagen is not a single substance; it is composed of a group of gelatin. There are two kinds of collagen, the first one is collagen with the behaviour of gelling, thickening, texturizing, and binding. The second type is related to collage surface characteristics such as foaming, stabilizing, emulsion, cohesion and adhesion, film-forming, and protectiveness. Because of its biodegradability and biocompatibility, it has ample applications in cosmetics, pharmaceuticals, biomedicals, food industries, film/adhesive industries, and tissue engineering [40].

Gelatin is the most abundant type of collagen, which is obtained from animal biomass. It is synthesized by partial hydrolysis of collagen derived from bones, cartilages, skins of animals, and tendons. It is slightly yellow in color or colorless, solid, brittle, odorless, and almost tasteless [41]. Gelatin commonly exists in the form of granular powder; however, sheet gelatin is still available in European countries [41]. In contrast to circular globular proteins, gelatin and collagen are a sclera protein that is found as linear fiber-like hierarchical structures [42].

Extraction of collagen/gelatin can be done by alkaline or acid treatment of leather biomass as shown in Figure 7. However, the biomass like splitting waste or vegetable tanned leather waste that does not contain chromium is recommended for applications of collagen/gelatin in cosmetics, food industries, and medical sectors. Therefore, collagen/gelatin can be extracted from leather biomass, which has several industrial applications such as adhesive, dye and plaster, textile, paper, cosmetics, foodstuff, pharmaceuticals, biogas production, edible packaging, and biofuel production [43].

5.2. Application in Cosmetic Formulation. Collagen is one of the main components of hide and skin, which is responsible for its condition and appearance. Owing to its insolubility in water, hydrolyzed collagen is mainly applied in cosmetic formulations. Hydrolyzed collagen has a penetrating effect on the epidermis and acts as a waterholding agent there. Short polypeptides and small peptides are water-soluble and can be easily added to the formulation of cosmetics. It has film-forming characteristics used for skin covering. It reduces water loss of transepidermal having a protective effect on hair or skin, which avoids harms caused by surfactants. Collagen is applied to the skin to provide smoothness and moisturizing effect. One of the greatest successful commercial uses of collagen is its dermatological defect repair by 
TABLE 1: Quantities of solid waste produced in tanneries [33].

\begin{tabular}{lcccc}
\hline Waste type & Beam house $(\mathrm{kg})$ & Pre-tanning $(\mathrm{kg})$ & Tanning $(\mathrm{kg})$ & Finishing $(\mathrm{kg})$ \\
\hline Trimmings & 90 & 120 & 110 & 115 \\
Wet blue split & - & & - & - \\
Fleshing & - & $70-230$ & - & - \\
Hair waste & $60-100$ & - & - & 225 \\
Buffing dust & $150-190$ & $190-350$ & - \\
Total & \multicolumn{2}{c}{ Approximate 600-800 } \\
Grand total & \multicolumn{4}{c}{} \\
\hline
\end{tabular}

TABLE 2: Chemical constituent of skins and hides [35].

\begin{tabular}{|c|c|c|c|c|}
\hline \multirow[b]{2}{*}{ Age of animals } & \multicolumn{4}{|c|}{ Percentage } \\
\hline & Moisture & $\begin{array}{c}\text { Protein (keratin, collagen, reticulin, } \\
\text { and elastin) }\end{array}$ & Fat & $\begin{array}{c}\text { Ash (sodium arsenic phosphorous, Potassium, } \\
\text { magnesium, calcium) }\end{array}$ \\
\hline Mature cattle hide, without hair & 65 & 30 & & \\
\hline Average slaughter cattle hides & $62-70$ & & & 1.0 \\
\hline Very fat animal & & & $10-12$ & \\
\hline Air-dried cattle hide & 9.1 & 89.9 & 0.2 & 0.8 \\
\hline Wet cattle hide & 83 & 15.7 & 0.2 & 0.1 \\
\hline New born calf & 67.9 & 30.8 & 1.0 & 1.0 \\
\hline Two-year-old steer & 61.2 & 35.0 & 3.2 & 1.1 \\
\hline Three-month-old calf & 66.0 & 31.0 & 1.6 & 1.4 \\
\hline Four-year-old steer & 55.6 & 38.2 & 6.0 & 1.1 \\
\hline Sheepskin & & & $30-50$ & 1.1 \\
\hline Old cow & 60.2 & 36.0 & 3.1 & \\
\hline Goatskin & 60.0 & & $3-10$ & \\
\hline Cured cattle hide & $44-48$ & 41 & & $14-16$ \\
\hline Pigskin & 37.0 & 14 & 30.50 & \\
\hline
\end{tabular}

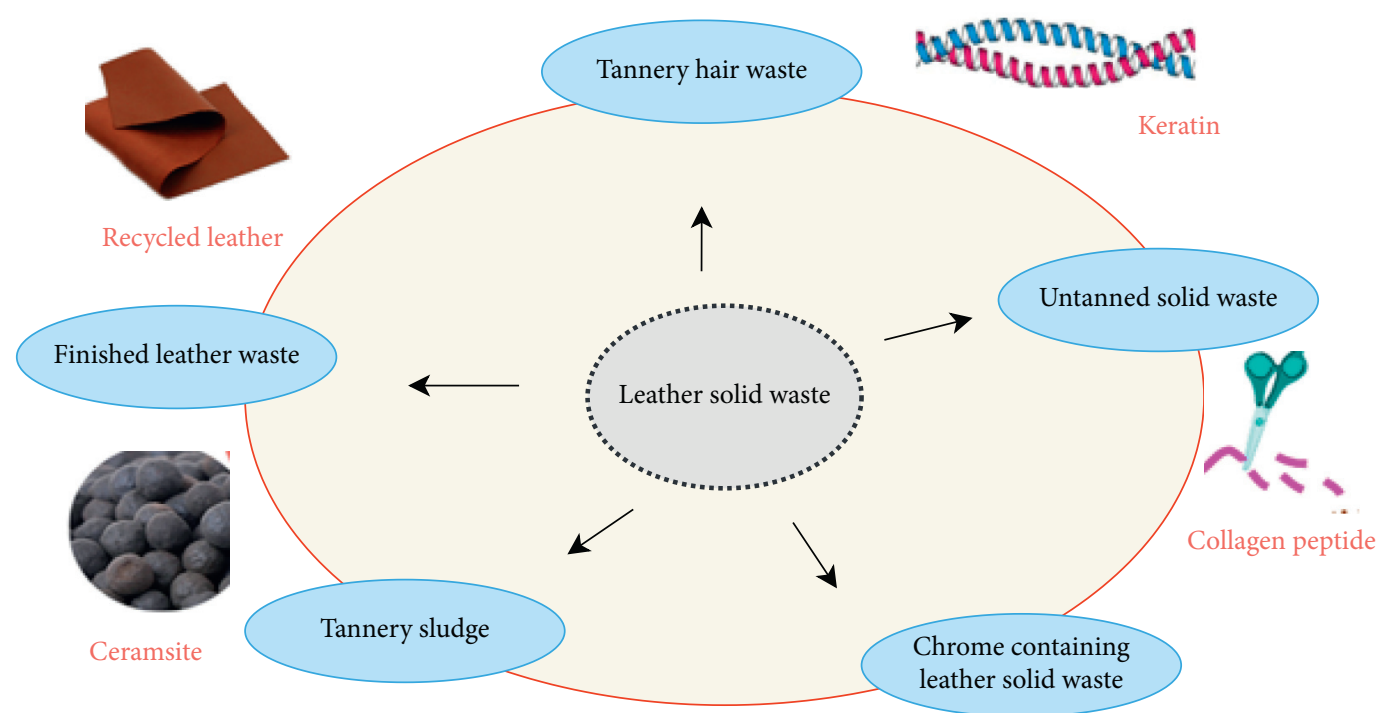

Figure 6: Application of solid skins and hides waste [36].

subcutaneous injection. In addition, collagen is used in lotion, moisturizing cream, and hair spray [44, 45].

\subsection{Application in Medical and Pharmaceutical Industries.} Gelatin and collagen have a variety of safe medical uses such as drug delivery, tissue engineering, scaffold, nanocarriers for anticancer therapeutics, and pharmaceutical uses. The annual consumption of gelatin and collagen in the medical sector is about 50,000 MT. Collagen and gelatin are mostly used in medical and pharmaceutical applications due to their biocompatibility with physiological situations and biodegradability $[46,47]$.

Due to its biodegradability, nontoxicity, inertness, nonirritating nature, and biocompatibility, gelatin is used in the manufacturing of drug delivery carriers. The carboxylic and amine group in gelatin gives modification to its 


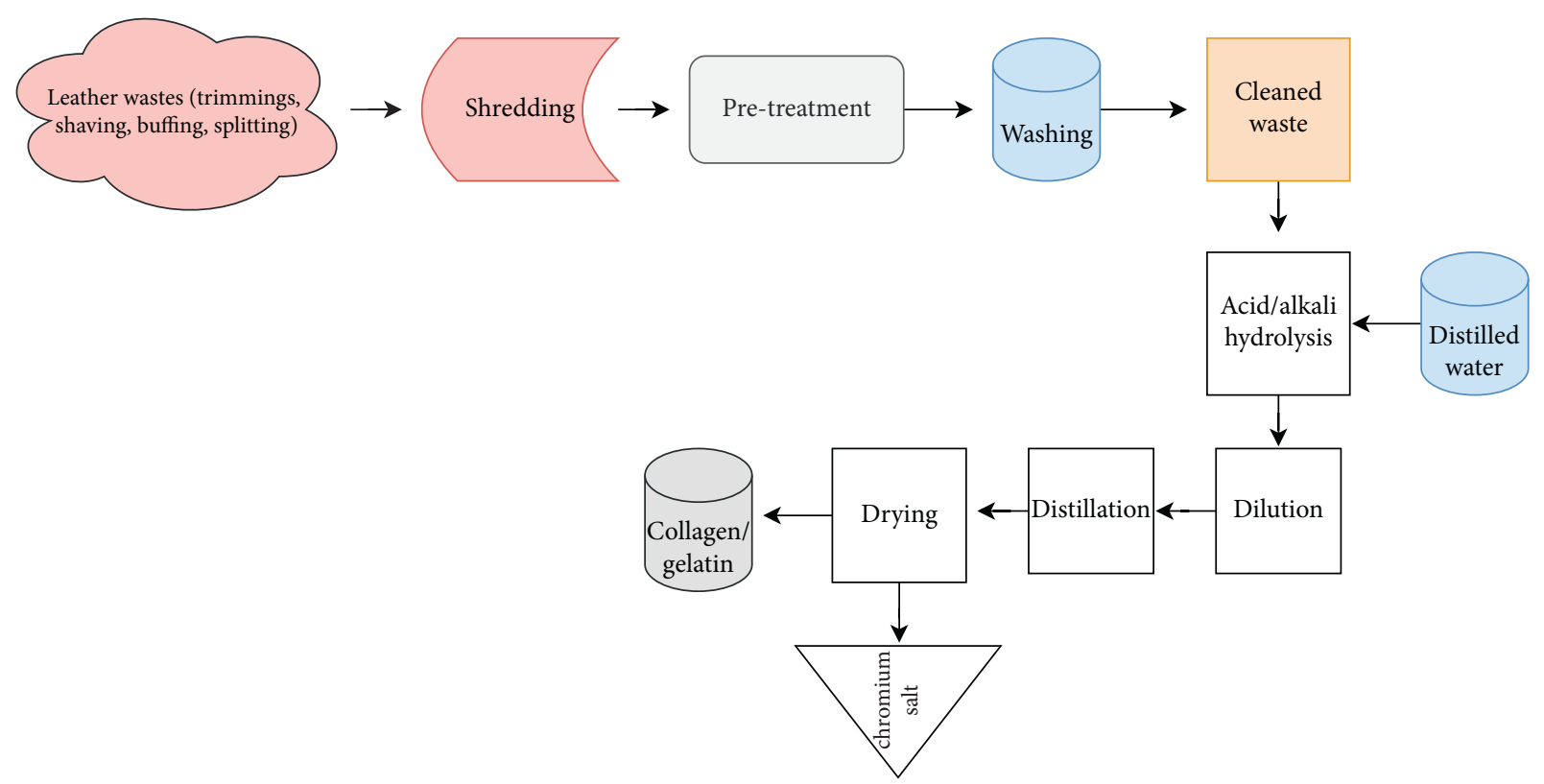

Figure 7: Collagen/gelatin extraction process from leather waste.

structure like protecting agents, cross-linkers, and couplings. Polymeric-based nanoparticles obtained from gelatin is used in cancer drug delivery because of its particle size, drug loading capacity, enzymatic degradation, degree of crosslinking (due to amine functional group), and drug content $[48,49]$. Gelatin is also used as a scaffold material for cardiovascular diseases. Due to its low cost, biodegradability, and natural origin, gelatin is the preferred biopolymer in tissue engineering. It is used as a coating agent in the regeneration of vascular tissue engineering, which enhances the cell attachment due to its compatibility with the tissue (both have carboxylic and amine functional groups) [50]. In addition, gelatin and collagen also have medical applications in wound dressing and implants.

About $6.5 \%$ of gelatin from total production is used in the pharmaceutical industry [51]. For the last several decades, gelatin has been playing a significant role in the pharmaceutical industries. It is known for its thermo-reversible gelling, filmforming, and adhesive nature. Pharmaceutical grade gelatin is largely used for vitamin implanting and the formation of capsules. It is used as the main component in protective gel-like zinc for the treatment of ulcerated varicose veins. In addition, it can be prepared into a sterile sponge by treating it with formaldehyde, whipping it into foam, and drying. Such kinds of sponges are used to implant antibiotics to the specific area and in surgery. Since gelatin is a proteinase material, it is used in plasma expanders for blood in cases of very serious injury and shock [52].

5.4. Application in Food. Collagen is one of the most wanted ingredients in the healthy production of food. Naturally, the production of collagen in the human body is decreasing with the increment of age; therefore, it has to be added to the diet to gain the appropriate protein in the body. As a result, it is mixed in a variety of diet products. Collagen is used as a food additive that is mixed into the food during processing to provide a rheological characteristic [53]. Studies showed that collagen treated with heat is used as an emulsifier in the formulation of food mostly in the acidic diet. In addition, collagen is used in the edible film as a coating material to protect the migration of moisture, oxygen, and salts that give vapor permeability and integrity to the food and in the extension of food shelf time [54]. "Edible coatings can improve the quality of fresh, frozen, and processed meat, poultry, and seafood products by retarding moisture loss, reducing lipid oxidation and discoloration, enhancing product appearance in retail packages by eliminating dripping" [55].

The applications of gelatin in food processing industries are very wide. These are lubrication, enhancing food elasticity, stability of food products, and consistency [56]. It is also used as a food stabilizer mainly as a fat replacement in dairy products and preparation of jelly-like desserts due to its "melt in mouth" characteristics. It is also broadly used in stabilizing frozen dessert and ice cream and also as a solvent in marshmallow and candy preparation. Recently, it has got use in the preparation of low-fat margarine production as an extender and emulsifier [57].

5.5. Application in Edible Food Packaging. The natural polymers have been used in biopolymer-based coating and film in food industries. It protects the food from outside contamination and prolongs the shelf-time of the food by maintaining its quality. The use of gelatin for the packing of highly delicate foods like fish and meat is highly recommended [58].

\subsection{Application of Leather Waste in Bioenergy}

5.6.1. Leather Waste in Biofuel. There is a rising demand for leather biomass such as greases and fats as a renewable energy source. Their use as an energy source is rising due to 
many reasons. The first reason is that their direct use in industrial burners contributes to the generation of energy at a relatively lower price. Second, the growing demand for biodiesel as a replacement for fossil fuels increases its demand. Currently, much of the biodiesel is obtained from soybean oil and canola oil [56]; however, many biodiesel production plants are growing, which uses only animal grease and fat as a raw material. Since such industries are at the start of major expansion, it might be difficult to predict the ultimate future impact. But, the growth will result in a bigger demand for animal greases and fats [59].

Biodiesel fuel obtained from the fats and oils of leather waste can be a potential replacement for diesel fuels obtained from petroleum. The availability of biomass from industrial processes and the desire to meet environmental conservation stand as the key motivations towards exploring all choices in waste management [5]. In this regard, the waste that contain fats from leather industries can be the future alternative to replace fossil-based fuels.

5.6.2. Leather Waste in the Biogas Industry. "The revised Renewable Energy Directive (REDII) requires the European Union (EU) to produce $32 \%$ of its energy consumption and at least $14 \%$ of its total fuel consumption with renewable energy sources by 2030." There are many renewable sources of starting materials in use for the production of biogas, leather biomass being one of them. Leather industries generate a huge quantity of waste in the form of liquid and solid, which are responsible for environmental pollution unless handled properly [56]. The use of leather industry biomass as secondary biofuel with thermal recycling in power plants has been stated to be achievable. Despite this, cattle manure, skin/hide, and leather industry waste are also important for electric power and biogas production, whereas solid waste generated from the leather processing industry is used as fuel in the cyclonic combustor [56]. In addition, anaerobic dissection is the most known method for the production of biogas with a complete recovery of carbon dioxide $\left(\mathrm{CO}_{2}\right)$ and methane in the absence of oxygen $[60,61]$.

5.7. Leather Biomass as Adsorbent Material. Adsorption is a simple method commonly used in the treatment of waste. The material used as an adsorbent in the process of adsorption shall have properties like high surface area, high selectivity and high adsorption capacity, the possibility of reuse, and a long useful life. In this regard, obtaining adsorbent material from tannery waste having carbonaceous nature that is appropriate to produce activated carbon, generate low-cost adsorbent, and reduce the volume of sludge is inspiring. This is because it can be used by the tannery industry itself in effluent treatment [62].

The activated carbon obtained from flashing waste by the pyrolysis process has thermal resistance, a greater number of surface functional groups, and greater porosity, compared to commercial activated carbon [63]. From chrome tanned leather, $97 \%$ removal of chromium (VI) was achieved. The activated carbon synthesized from vegetable-tanned leather waste was used as an adsorbent material and removes $90 \%$ of dyes. In addition, shaving waste also showed encouraging adsorption in the reduction of inorganic and organic contaminants and color that allows for the recycling of effluents from tanneries. The activated carbon prepared from chromium-tanned leather shavings exhibited a higher affinity and around $50 \%$ capacity of adsorption [64].

5.8. Leather Waste in Biosurfactant Synthesis and Application. Surfactants are amphiphilic compounds containing hydrophilic (water-soluble) heads and hydrophobic (lipophilic; water-insoluble) tails. They are soluble in both water and other organic kinds of solvents due to these two characteristics. The hydrophilic parts of surface-active agents are ionic or nonionic and the hydrophobic parts are branched or straight fluorocarbon or hydrocarbons chain with a carbon atom of 8-18 [65]. Surface active agents are compounds that can change the interface between two solids and liquid or between two liquids. Change or modification between the two parts is achieved with the combined effect of surfactant molecules; one part (hydrophilic) dissolves in water and the other part (hydrophobic) dissolves in oil or lipid phase connecting both immiscible phases. $0.1-1 \%$ concentration of surfactant application is sufficient to reduce the surface tension of the two phases since it is applied at the interfacial portion [66].

The conventional surfactant manufacturing process is based on petrochemical sources or a mixture of petrochemical and renewable sources [67]. However, the need for renewable, sustainable, and biodegradable production of biosurfactant is increasing due to the depletion of petroleum and the environmental impact of petrochemical-based surfactants. The world market for surfactants exceeded 15 MT annually [68].

Biosurfactants obtained from natural sources have several advantages over petrochemical-based surfactants. These are, economically feasible, environmentally friendly (low toxicity), easily biodegradable, biocompatible, has renewable starting material, and cheaper starting material [69]. In the synthesis of the surfactant, the natural raw material can be incorporated as a hydrophobic or hydrophilic building block. Cellulose, amino acids, and sugar are hydrophilic types of building blocks used in surfactant manufacturing [70].

In general, leather processing industry waste can be used as a source of building blocks of surfactants and the fat obtained from the tannery waste is the main source of surfactants. The amino acid that is synthesized by acid hydrolysis of protein-containing leather wastes like shaving, splitting, fleshing, and other related wastes are the main building block of a biocompatible and biodegradable surface-active agent [71]. Condensation of natural amino acid and fatty acid results in amino acid surfactants and the polar group of amino acids characterizes it as the building block of amino acid surfactants. Figure 8 shows different amino acidbased surfactants. Biosurfactant is usually used as a detergent, wetting agent, emulsifiers, softening agent, dispersing agent, solubilizing agent, and foaming agent. They do have 


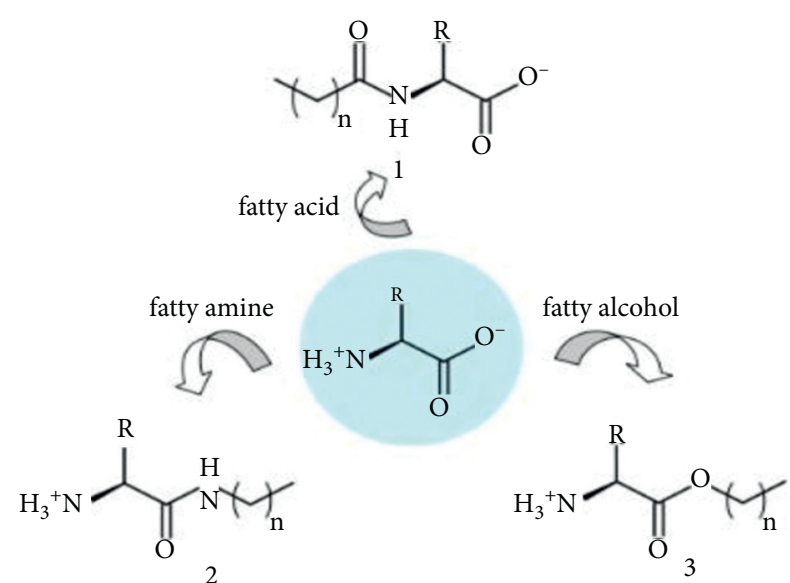

FIGURE 8: Type of amino acid-based surfactant acyl (1), ester (2), and amine (3) bond derivatives (adopted from [72]).

applications in several industries like textiles, pharmaceuticals, food, petroleum, paper products, cosmetics, organic chemicals, and biotechnologies [72, 73]. The following section describes some of the applications of biosurfactants.

5.9. Biosurfactant Applications in Textile. Textile material undergoes sequences of wet processing actions to produce a different functional fabric. Wet processing is one of the most important processes in the textile value chain and consumes a large volume of surfactants. Surfactant has a large application in textile processing as an emulsifier/dispersing agent, soaping agent/detergent, wetting agent, and lubricant/softening agent [74]. It plays a significant role in the dyeing, pre-treatment, printing, and finishing of textile fabric to meet the requirements of the quality of the fabric. Surfactants like detergents and wetting agents reduce the water surface tension from $0.073 \mathrm{~N} / \mathrm{m}$ to $0.030 \mathrm{~N} / \mathrm{m}$ by covering (expanding over) the surface of the liquid (water) and facilitate penetration of dyes and chemicals. It is used in the de-sizing, scouring, bleaching, printing, and dyeing process of textile material. Due to its outstanding adhesive characteristics, the surfactant of amino acid is an ideal softening agent and lubricant in textiles $[74,75]$. Biosurfactants are accepted in the replacement of petroleumbased surfactants due to their sustainability, biodegradability, less effluent load, being economically viable, and cheaper starting material (the leather waste in this case) [76]. As a result, an amino acid-based surfactant can be the potential replacement for petroleum-based surfactants for textile applications.

\subsection{Medical Application of Biosurfactants}

5.10.1. Drug Delivery. Due to their low toxicity, biodegradability, and biocompatibility (presence of amine group), amino acid surfactant (fatty acyl type) is one of the biomaterials in drug delivery. It has the advantage of increasing the solubility of the drug and shielding it from degradation. "Cells usually take up drug carriers through endocytosis that limits the internalized active compounds to vesicles (endosomes)." Properties of the surface, like surface charge and hydrophobicity, have a main effect on the cellular take-up of delivery of the drug system. Hence, the insertion of ionic surfactants into the carriers can improve directing to the specific cells [72].

5.10.2. Gene Delivery. Gene therapy is a medical method used to restore the faulty gene by replacing defective genes with the normal gene. Efficient therapy of gene is based on the carrier of the gene, and effective gene transfer to the cell is the main task to achieve the goal. Gemini amino acidbased surfactant is used as a carrier to accomplish the transfer of genes to the cell due to its biocompatibility and biodegradability $[77,78]$.

5.10.3. Antiviral Activity. Recently, many scholars are attracted by the use of bio-based inhibiters of viral diseases like lipoamino acid. In this regard, the derivative of acyl amino acid is reported as an inhibitor of influenza neuraminidase. Cationic surfactant derivative of amino acid surfactant synthesized by the fatty acid condensation is known for its protection from microorganisms and viral contagions [79].

5.11. Biosurfactant Application in Agriculture. Improving the productivity of the agricultural sector is one of the vital issues since the need for food is increasing due to the growth of the population in the world. The production process needs to be eco-friendly using the biological method to protect the environment and soil and also shall be sustainable to secure food supply. Surfactants are used in several areas of agriculture such as agrochemical formulation and crop protection. Biosurfactants can be a replacement for synthetic surfactants and are significant in agricultural areas as they improve the soil quality. They contribute to an indirect promotion of plant growth as they have an antimicrobial action that improves microbial interaction of plants, as shown in Figure 9. In addition, biosurfactants are found to be the substitutes for synthetic surfactants currently utilized in pesticide manufacturing.

Biosurfactants obtained from renewable sources such as amino acid surfactants can be utilized in herbicide, insecticide, and inhibitors of plant growth in the agricultural sector. A US patent reported that grass pesticide has been produced using the blend of refined Cupressaceae family of plant and surfactant solution extracted from amino acids $[80,81]$.

5.12. Biosurfactant Application in the Food Processing Industry. Food industries have been using surfactants for several centuries as an emulsifier in food formulation. Understanding of structure, properties, and formulation of an emulsion is very important in the stabilization and creation of food structure and textural stability. There are three kinds of emulsion in food formulation. The first is oil-in-water $(\mathrm{o} / \mathrm{w})$ emulsion in which oil droplets are suspended in a continuous aqueous phase. This emulsion is found in foods such as cream liqueur, creamers, ice creams mixes, and mayonnaises. The second emulsion type is waterin-oil (w/o) emulsion and in this emulsion, water is 


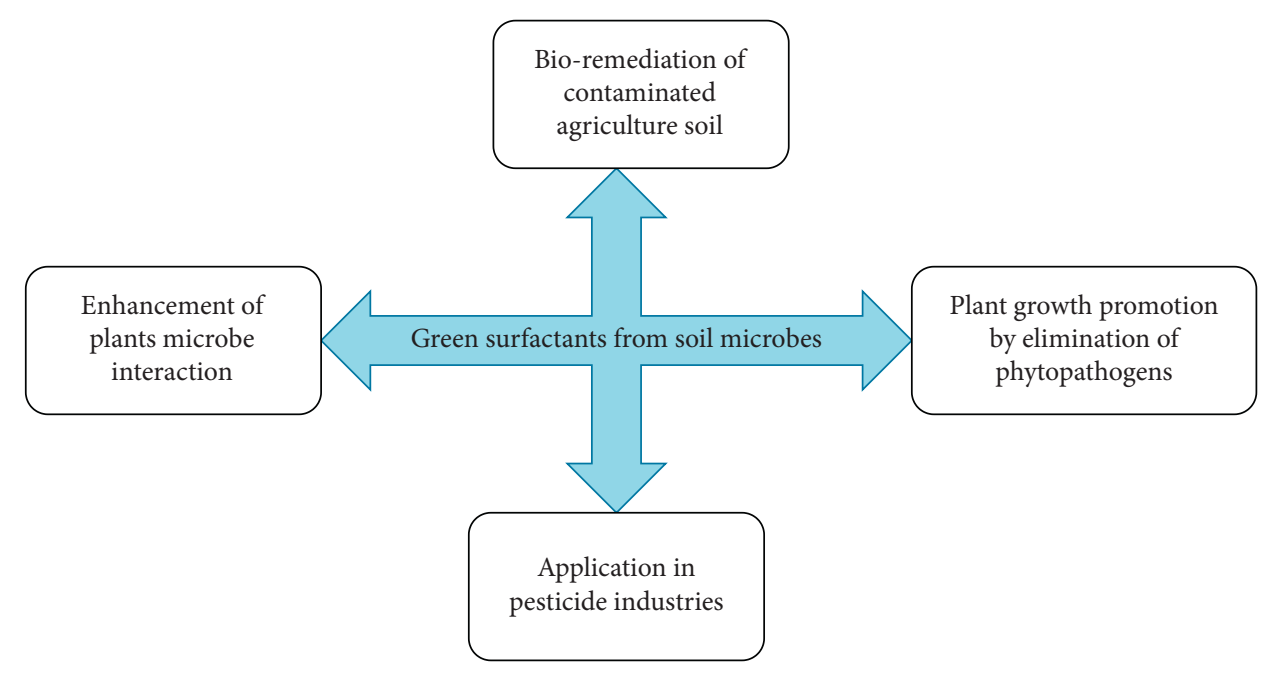

FIGURE 9: Multifunctional prospective biosurfactant application in agriculture (adopted from [80]).

suspended in a continuous oily phase and it exists in margarine, butter, and fat-based spreads. The third one is water-in-oil-in-water (w/o/w) emulsion and it is found in packed foods of various types $[82,83]$. The emulsion process is shown in Figure 10. Amino acid surfactants are used widely as bio-surfactant (emulsifiers) in food processing industries as dairy products, margarine, dressing, and lowcalorie spread. Due to its wide antibacterial spectra and antimicrobial effect, the amino acid surfactant has got great attention in the selection of surfactants in food formulation and has become a promising alternative to synthetic surfactant [72].

5.13. Biosurfactant Application in the Cosmetic Industry. In the choice of surfactants for cosmetic, pharmaceutical, and personal care products, mildness, toxicity, safety, environmental issues, and gentleness are the main concerns. Amino acid surfactants are biosurfactants used in many personal care product formulations and are preferred over synthetic-based surfactants due to the environmental impact and nonrenewability of the latter. Amino acid surfactants with C12 carbon chain fatty acid is widely used in the cleaning of makeup and soil from the face, whereas C18 carbon chain amino acid surfactants are used as an emulsifier in cosmetics for skincare. In addition, amino acid surfactants have many uses in hair softeners, shampoos, rinses. It is also used in hair treatment, which reduces the breakage of hair by penetrating through the cuticle into the hair chute and drawing the moisture from the skin $[72,84]$. The presence of the amine group in the amino acid surfactant makes it compatible and suitable for cosmetic applications.

\section{Main Challenges Related to Valorization}

Several challenges in relation to biomass valorization have been recognized and research needs to face them identified [1]. Although the leather industry biomass has several application areas as mentioned above, some challenges must be considered during the conversion of this biomass to biomaterial and bioenergy. The following paragraphs illustrate the main challenges in the utilization of leather industry biomass for various applications.

The key challenge in the production of biogas from a chromium-tanned biomass of leather is the production efficiency. Compared to other types of biomasses, chromium (III) eliminates organic matter from the leather, which is responsible for anaerobic digestion during the production of biogas [85].

The main problem in the manufacturing of biodiesel from leather biomass is the development of detergent in the trans-esterification stand out that needs viscosity, pre-treatment, and cloud point. Therefore, an investigation is required to improve the parameters, since the use of this plentiful biomass as an alternative starting material can help in the sustainable supply of biodiesel demand [85].

Although promising results have been observed in the application of leather wastes for adsorbent material, further study is needed on activated carbon obtained from tannery waste to ensure multicomponent removal of contaminants. The major challenge that must be addressed is attention to the possibility of regeneration of material, in addition to economic feasibility joined with good removal capability.

Even though the by-products of tannery have promising applications for the production of fertilizer, there are some issues to be addressed regarding their use. "Application of wastewater from the tannery effluent treatment plant limited the growth and development of wheat biomass" [86]. Such an effect can be associated with the accumulation of metals in the soil, such as chromium, promoting stress in plants, and reducing the action of antioxidant molecules [87]. It is imperative to mention the adverse impact of chromium on the growth of plants. Oxidation of chromium in $\mathrm{Cr}^{6+}$ depends on the movement and availability of other inorganic and organic 


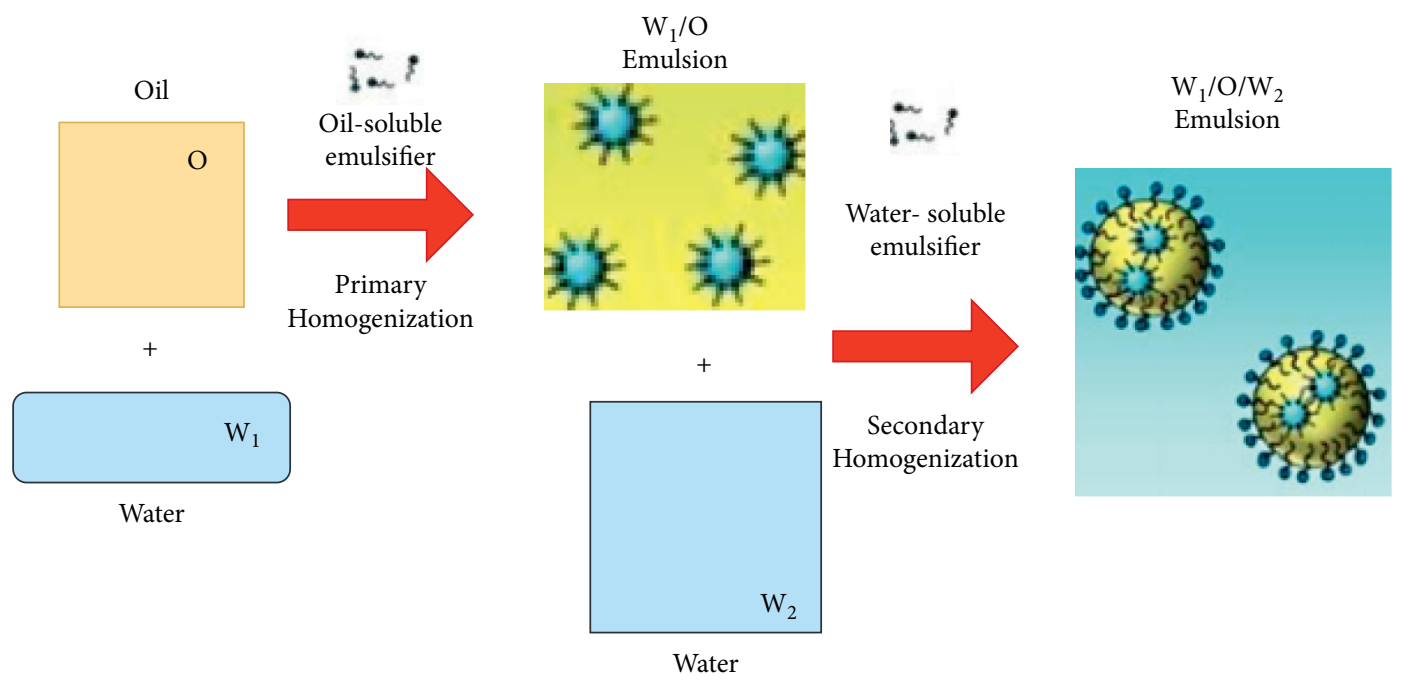

FIGURe 10: (i) Primary homogenization: an aqueous and oil phase are homogenized together in the existence of an oil-soluble emulsifier to make a W/O emulsion; (ii) secondary homogenization: The W/O emulsion is homogenized with a water phase in the existence of a watersoluble emulsifier to form a W/O/W emulsion (adopted from [82]).

compounds that exist in the soil. To overcome such a problem, fulvic acid can be added to reduce the toxic impact of chromium [88].

Furthermore, the application of biomaterial obtained from tannery biomass for medical and pharmaceutical applications, food processing, and edible food packaging need great attention. Appropriate purification (pretreatment) process shall be provided to tannery biomass to reduce toxic chemicals incurred in the tanning process. However, for other applications like paper and pulp, and textiles, direct application is possible.

\section{Conclusions}

The tanning industry worldwide release approximately 1.4 MT solid biomass every year, and landfilling is a major method of disposal. Landfilling of leather biomass creates problems such as contamination of soil and water, increasing levels of global warming, and making land unsuitable for use due to bioaccumulation of pollutants. However, many studies have shown that leather biomass can be a renewable raw material for the production of sustainable and eco-friendly biomaterials. Leather biomass mainly contains protein (30-35\% collagen) and fat. They are the raw material for high-value materials like biofilms, bioplastics, biofiber, superabsorbent material, additives in various industries, sizing agent, and surfactants, and can be considered as a replacement for fossil-fuel-based materials. Therefore, there is no better way than utilizing this biomass for value-added material production that impact the economy positively and being a primary solution for prevention of pollution.

The results of this review demonstrated that more than 19 high-value products can be produced from leather processing industry biomass. Biomaterials obtained from leather biomass have various applications in the biomedical and pharmaceutical industries, food industries, cosmetics, biofuels, paper sizing, adhesives, textile industries, and many others. Several promising results have been reported. The conversion of leather biomass to biomaterials integrates bioeconomy and promotes circular economy. To establish circular bioeconomy, the particular implication of biomass use needs to be appreciated by stakeholders through the value chain, from product design to waste management.

However, many challenges need to be addressed to make a possible commercial product. Also, extensive research investigation and product development work must be explored for ample utilization of this waste material in addition to the methods discussed in this review. The utilization of leather waste has a significant contribution to the green economy and improves the profitability of tanneries by generating additional income.

As society progresses, we need to rely more on a sustainable bioeconomy. Moving towards a sustainable supply of biomaterials can be a clear strategy and priority solution for sustainable bioeconomy and to solve environmental challenges that must be addressed urgently.

\section{Data Availability}

All the figures are redrawn and uploaded as pdf. files.

\section{Conflicts of Interest}

The authors declare that they have no conflicts of interest.

\section{Acknowledgments}

The authors thank the Higher Education and TVET Program Ethiopia-Phase 3, PE479- Higher Education, KFW Project (No. 51235) and BMZ (No. 201166305) for the financial support of this research. 


\section{References}

[1] P. Manzanares, "The role of biorefinering research in the development of a modern bioeconomy," Acta Innovations, vol. 37, no. 37, pp. 47-56, 2020.

[2] K. Kohli, R. Prajapati, and B. Sharma, "Bio-based chemicals from renewable biomass for integrated biorefineries," Energies, vol. 12, no. 2, 2019.

[3] C. Lago, N. Caldés, and Y. Lechón, The Role of Bioenergy in the Emerging Bioeconomy: Resources, Technologies, Sustainability and Policy, Academic Press, Cambridge, MA, USA, 2018.

[4] A. Mardoyan and P. Braun, "Analysis of Czech subsidies for solid biofuels," International Journal of Green Energy, vol. 12, no. 4, pp. 405-408, 2015.

[5] M. Boario, Technical Assistance Project for the Upgrading of the Ethiopian Leather and Leather Products Industry, pp. 1105, UNIDO, Vienna, Austria, 2012.

[6] A. Yorgancioglu, B. Başaran, and A. Sancakli, "Value addition to leather industry wastes and biomasss: hydrolyzed collagen and collagen peptides," Waste in Textile and Leather Sectors, Intechopen, London, UK, 2020.

[7] J. Kanagaraj, K. C. Velappan, N. K. Babu, and S. Sadulla, "Solid wastes generation in the leather industry and its utilization for cleaner environment-A review," ChemInform, vol. 37, 2006.

[8] H. Ozgunay, S. Çolak, M. M. Mutlu, and F. Akyuz, "Characterization of leather industry wastes," Polish Journal of Environmental Studies, vol. 16, no. 6, 2007.

[9] L. S. Simeonova and P. G. Dalev, "Utilization of a leather industry waste," Waste Management, vol. 16, no. 8, pp. 765-769, 1996.

[10] CTC, Wastes Generated In The Leather Products Industry, UNIDO, Vienna, Austria, 2000.

[11] J. Sherwood, "The significance of biomass in a circular economy," Bioresource Technology, vol. 300, Article ID 122755, 2020.

[12] S. Leipold and A. Petit-Boix, "The circular economy and the bio-based sector - p," Journal of Cleaner Production, vol. 201, pp. 1125-1137, 2018.

[13] M. Parisi, A. Nanni, and M. Colonna, "Recycling of chrometanned leather and its utilization as polymeric materials and in polymer-based composites: a review," Polymers, vol. 13, no. 3, 2021.

[14] J. C. Hughes, "The disposal of leather tannery wastes by land treatment, a review," Soils use and management, vol. 4, no. 3, pp. 107-111, 1988.

[15] D. W. Nazer, R. M. Al-Sa'ed, and A. Siebel, "Reducing the environmental impact of the unhairing-liming process in the leather tanning industry," Journal of Cleaner Production, vol. 14, no. 1, pp. 65-74, 2006.

[16] C. Piera Framis, Assessment of Tannery Solid Waste Management: A Case of Sheba Leather Industry in Wukro (Ethiopia), Bachelor's thesis, Universitat Politècnica de Catalunya, Barcelona, Spain, 2018.

[17] A. Nanni, M. Parisi, M. Colonna, and M. Messori, "Thermomechanical and morphological properties of polymer composites reinforced by natural fibers derived from wet blue leather wastes: a comparative study," Polymers, vol. 13, no. 11, p. $1837,2021$.

[18] J. Maroušek, S. Hašková, R. Zeman et al., "Polemics on ethical aspects in the compost business," Science and Engineering Ethics, vol. 22, no. 2, pp. 581-590, 2016.

[19] S. Swarnalatha, T. Srinivasulu, M. Srimurali, and G. Sekaran, "Safe disposal of toxic chrome buffing dust generated from leather industries," Journal of Hazardous Materials, vol. 150, no. 2, pp. 290-299, 2008.

[20] D. Q. Lima, L. C. A. Oliveira, A. R. R. Bastos et al., "Leather industry solid waste as nitrogen source for growth of common bean plants." Applied and Environmental Soil Science, vol. 2010, Article ID 703842, 7 pages, 2010.

[21] O. Yılmaz, I. C. Kantarli, M. Yuksel, M. Saglam, and J. Yanik, "Conversion of leather wastes to useful products," Resources, Conservation and Recycling, vol. 49, no. 4, pp. 436-448, 2007.

[22] A. Teklay, G. Gebeyehu, T. Getachew, T. Yaynshet, S. Inbasekaran, and T. P. Sastry, "Preparation of valueadded composite sheet from solid waste leather-a prototype design," Scientific Research and Essays, vol. 13, no. 2, pp. 11-13, 2018.

[23] F. G. Nogueira, I. A. Castro, A. R. Bastos, G. A. Souza, J. G. de Carvalho, and L. C. Oliveira, "Recycling of solid waste rich in organic nitrogen from leather industry: mineral nutrition of rice plants," Journal of Hazardous Materials, vol. 186, no. 2-3, pp. 1064-1069, 2011.

[24] E. Malavolta, Manual De Nutrição Mineral De Plantas, Agronômica Ceres, Sao Paulo, Brazil, 2006.

[25] A. Gessesse, F. Mulaa, S. L. Lyantagaye, L. Nyina-Wamwiza, B. Mattiasson, and A. Pandey, Industrial Enzymes for Sustainable Bio-Economy: Large Scale Production and Application in Industry, Environment, and Agriculture in Eastern Africa, Cgiar, Montpellier, France, 2011.

[26] M. Catalina, A. P. M. Antunes, G. Attenburrow, J. Cot, A. D. Covington, and P. S. Phillips, "Sustainable management of waste-reduction of the chromium content of tannery solid waste as a step in the cleaner production of gelatin," Journal of Solid Waste Technology and Management, vol. 33, no. 1, pp. 43-50, 2007.

[27] H. Berhanu, Determination of Optimum Condition for the Production of Commercially Viable Glue from Tannery Solid Waste, Addis Aabaa Institute of Technology, Addis Ababa, Ethiopia, 2011.

[28] P. G. Dalev and L. S. Simeonova, "An enzyme biotechnology for the total utilization of leather wastes," Biotechnology Letters, vol. 14, no. 6, pp. 531-534, 1992.

[29] J. Artola and O. Grib, "Method of tanning and washing leather, canvas, cotton and any other materials, as well as the finished product," U.S. Patent US9708675B1 9,708.675, 2017.

[30] P. Saikia, T. Goswami, D. Dutta, N. K. Dutta, P. Sengupta, and D. Neog, "Development of a flexible composite from leather industry waste and evaluation of their physico-chemical properties," Clean Technologies and Environmental Policy, vol. 19, no. 8, pp. 2171-2178, 2017.

[31] J. Kong, Q. Yue, L. Huang et al., "Preparation, characterization and evaluation of adsorptive properties of leather waste based activated carbon via physical and chemical activation," Chemical Engineering Journal, vol. 221, pp. 62-71, 2013.

[32] M. Thomas, T. Van Vliet, and A. F. B. Van der Poel, "Physical quality of pelleted animal feed 3. Contribution of feedstuff components," Animal Feed Science and Technology, vol. 70, no. 1-2, pp. 59-78, 1998.

[33] R. O. Oruko, W. N. Moturi, and J. M. Mironga, “Assessment of tannery based solid wastes management in asili, nairobi Kenya," International Journal for Quality Research, vol. 8, no. 2, 2014.

[34] L. F. Cabeza, M. M. Taylor, G. L. DiMaio et al., "Processing of leather waste: pilot scale studies on chrome shavings. Isolation of potentially valuable protein products and chromium," Waste Management, vol. 18, no. 3, pp. 211-218, 1998. 
[35] S. Akter, S. M. S. Shahriar, F. Akter, S. Morshed, and M. N. Islam, "Study on chemical composition of fresh Mymensingh and Barishal hog-plum (Spondius mangifera) and developed leather and jelly and sensory evaluation," Journal of Environmental Science and Natural Resources, vol. 5, no. 2, pp. 29-36, 2012.

[36] K. Jayathilakan, K. Sultana, K. Radhakrishna, and A. S. Bawa, "Utilization of byproducts and waste materials from meat, poultry and fish processing industries: a review," Journal of Food Science \& Technology, vol. 49, no. 3, pp. 278-293, 2012.

[37] S. Famielec, "Environmental effects of tannery waste incineration in a tunnel furnace system," Proceedings of ECOpole, vol. 9, no. 2, pp. 441-450, 2015.

[38] G. N. Ramachandran and G. Kartha, "Structure of collagen," Nature, vol. 174, pp. 269-270, 1954.

[39] T.-K. Kim, Y.-K. Ham, D.-M. Shin et al., "Extraction of crude gelatin from duck skin: effects of heating methods on gelatin yield," Poultry Science, vol. 99, no. 1, pp. 590-596, 2020.

[40] S. Nalinanon, S. Benjakul, W. Visessanguan, and H. Kishimura, "Improvement of gelatin extraction from bigeye snapper skin using pepsin-aided process in combination with protease inhibitor," Food Hydrocolloids, vol. 22, no. 4, pp. 615-622, 2008.

[41] U. ur Rahman, A. Sahar, and M. Azam Khan, "Recovery and utilization of effluents from meat processing industries." Food Research International, vol. 65, pp. 322-328, 2014.

[42] J. Li, X. Wang, T. Zhang et al., "A review on phospholipids and their main applications in drug delivery systems." Asian Journal of Pharmaceutical Sciences, vol. 10, no. 2, pp. 81-98, 2015.

[43] G. Artoni, "Process for gelatins extraction and chromium salts recovery from tanned hides and skins shavings," Artoni Sas di Artoni Giancarlo and Co, U.S. Patent EP1356007B1 7,077,966, 2006.

[44] A. Sionkowska, S. Skrzyński, K. Śmiechowski, and A. Kołodziejczak, "The review of versatile application of collagen," Polymers for Advanced Technologies, vol. 28, no. 1, pp. 4-9, 2017.

[45] V. J. Sundar, J. Raghavarao, C. Muralidharan, and A. B. Mandal, "Recovery and utilization of chromium-tanned proteinous wastes of leather making: a review," Critical Reviews in Environmental Science and Technology, vol. 41, no. 22, pp. 2048-2075, 2011.

[46] R. J. Babu, M. Annaji, A. Alsaqr, and R. D. Arnold, “Animalbased materials in the formulation of nanocarriers for anticancer therapeutics," in Polymeric Nanoparticles as a Promising Tool for Anti-cancer Therapeutics, pp. 319-341, Academic Press, Cambridge, MA, USA, 2019.

[47] J. Chesterman, Z. Zhang, O. Ortiz, R. Goyal, and J. Kohn, "Biodegradable polymers," in Principles of Tissue Engineering, pp. 317-342, Academic Press, Cambridge, MA, USA, 2020.

[48] P. Kesharwani, K. M. Paknikar, and V. Gajbhiye, Polymeric Nanoparticles as a Promising Tool for Anti-cancer Therapeutics, Academic Press, Cambridge, MA, 2019.

[49] D. Olsen, C. Yang, M. Bodo et al., "Recombinant collagen and gelatin for drug delivery," Advanced Drug Delivery Reviews, vol. 55, no. 12, pp. 1547-1567, 2003.

[50] R. Narayan, Encyclopedia of Biomedical Engineering, Elsevier, Amsterdam, Netherland, 2018.

[51] S. Benjakul, K. Oungbho, W. Visessanguan, Y. Thiansilakul, and S. Roytrakul, "Characteristics of gelatin from the skins of bigeye snapper, Priacanthus tayenus and Priacanthus macracanthus," Food Chemistry, vol. 116, no. 2, pp. 445-451, 2009.
[52] C. Meena, S. A. Mengi, and S. G. Deshpande, "Biomedical and industrial applications of collagen," in Proceedings of the Indian Academy of Sciences-Chemical Sciences, Springer India, April 1999.

[53] P. Hashim, M. Ridzwan, J. Bakar, and D. Hashim, "Collagen in food and beverage industries," International Food Research Journal, vol. 22, pp. 1-8, 2015.

[54] D. M. Greene, "Use of poultry collagen coating and antioxidants as flavor protection for cat foods made with rendered poultry fat," Doctoral dissertation, MSc thesis, Virginia Polytechnic Institute and State University, Blacksburg, VA, United States, 2003.

[55] J. Maroušek, A. Maroušková, K. Myšková, J. Váchal, M. Vochozka, and J. Žák, "Techno-economic assessment of collagen casings waste management," International journal of Environmental Science and Technology, vol. 12, no. 10, pp. 3385-3390, 2015.

[56] R. Karthikeyan, S. Balaji, and P. Sehgal, "Industrial applications of keratins-a review," American Journal of Scientific and Industrial Research, vol. 66, p. 710, 2007.

[57] T. R. Keenan, "Gelatin," Polymer Science: A Comprehensive Reference, Elsevier, Amsterdam, Netherland, 2012.

[58] M. Ramos, A. Valdes, A. Beltran, and M. C. Garrigós, "Gelatin-based films and coatings for food packaging applications," Coatings, vol. 6, no. 4, p. 41, 2016.

[59] V. V. Kulkarni and S. K. Devatkal, "Utilization of byproducts and waste materials from meat and poultry processing industry: a review," Journal of Meat Science, vol. 11, no. 1, pp. 1-10, 2015.

[60] M. Bonoli, C. Salomonia, A. Caputoa, O. Franciosob, and D. Palenzonaa, "Anaerobic digestion of high-nitrogen tannery biomasss in a multiphase process for biogas production," Chemical Engineering, vol. 37, 2014.

[61] R. Hadjadj, C. Deák, Á. B. Palotás, P. Mizsey, and B. Viskolcz, "Renewable energy and raw materials - the thermodynamic support," Journal of Cleaner Production, vol. 241, Article ID $118221,2019$.

[62] I. C. Kantarli and J. Yanik, "Use of waste sludge from the tannery industry," Energy \& Fuels, vol. 23, no. 6, pp. 3126-3133, 2009.

[63] Y. Palani, R. Rao Jonnalagadda, and N. Fathima Nishter, "Adsorption on activated carbon derived from tannery fleshing waste: adsorption isotherms, thermodynamics, and kinetics," Environmental Progress \& Sustainable Energy, vol. 36, no. 6, pp. 1725-1733, 2017.

[64] H. Jiang, J. Liu, and W. Han, "The status and developments of leather solid waste treatment: a mini-review," Waste Management \& Research: The Journal for a Sustainable Circular Economy, vol. 34, no. 5, pp. 399-408, 2016.

[65] B. E. Brycki, I. H. Kowalczyk, A. Szulc, O. Kaczerewska, and M. Pakiet, "Multifunctional gemini surfactants: structure, synthesis, properties and applications," Application and Characterization of Surfactants, pp. 97-155, IntechOpen, London, UK, 2017.

[66] H. C. Speel, "Surface active agents: chemical types and applications," Journal of Investigative Dermatology, vol. 6, no. 5, pp. 293-304, 1945.

[67] A. Bhadani, A. Kafle, T. Ogura et al., "Current perspective of sustainable surfactants based on renewable building blocks," Current Opinion in Colloid \& Interface Science, vol. 45, 2020.

[68] J. Li, X. Wang, T. Zhang et al., "A review on phospholipids and their main applications in drug delivery systems," Asian 
Journal of Pharmaceutical Sciences, vol. 201, no. 2, pp. 81-98, 2015.

[69] S. Biz and M. L. Occelli, "Synthesis and characterization of mesostructured materials," Catalysis Reviews, vol. 40, no. 3, pp. 329-407, 1998.

[70] M. Svensson, "Surfactants based on natural fatty acids," Surfactants from Renewable Resources, pp. 3-15, Wiley, Hoboken, NJ, USA, 2010.

[71] M. E. Bautista, L. Pérez, M. T. García, S. Cuadros, and A. Marsal, "Valorization of tannery wastes: lipoamino acid surfactant mixtures from the protein fraction of process wastewater," Chemical Engineering Journal, vol. 262, pp. 399-408, 2015.

[72] L. Pinheiro and C. Faustino, Amino Acid-Based Surfactants for Biomedical Applications. Application and Characterization of Surfactants, Intechopen, London, UK, 2017.

[73] R. El-Sayed, H. H. Alotaibi, and H. A. Elhady, "Synthesis, surface parameters, and biodegradability of water-soluble surfactants for various applications," Journal of Oleo Science, vol. 67, no. 5, pp. 551-569, 2018.

[74] C. Pacifico and S. Giers, "Surfactants used in textile applications," Journal of the American Oil Chemists Society, vol. 32, no. 4, pp. 231-235, 1955.

[75] C. N. Sivaramakrishnan, "The use of surfactants in the finishing of technical textiles," in Advances in the Dyeing and Finishing of Technical Textiles, pp. 199-235, Woodhead Publishing, Sawston, UK, 2013.

[76] S. J. Leighs, S. J. McNeil, and S. L. Ranford, "The application of biosurfactants for scouring wool," Coloration Technology, vol. 135, no. 1, pp. 48-52, 2019.

[77] M. Donkuru, I. Badea, S. Wettig, R. Verrall, M. Elsabahy, and M. Foldvari, "Advancing nonviral gene delivery: lipid- and surfactant-based nanoparticle design strategies," Nanomedicine, vol. 5, no. 7, pp. 1103-1127, 2010.

[78] M. Rosa, M. Rosa, N. Penacho et al., "DNA pre-condensation with an amino acid-based cationic amphiphile. a viable approach for liposome-based gene delivery," Molecular Membrane Biology, vol. 25, no. 1, pp. 23-34, 2008.

[79] M. Kondoh, T. Furutani, M. Azuma, H. Ooshima, and J. Kato, "Acyl amino acid derivatives as novel inhibitors of influenza neuraminidase," Bioscience Biotechnology and Biochemistry, vol. 61, no. 5, pp. 870-874, 1997.

[80] D. P. Sachdev and S. S. Cameotra, "Biosurfactants in agriculture," Applied Microbiology and Biotechnology, vol. 97, no. 3, pp. 1005-1016, 2013.

[81] H. Bee, M. Y. Khan, and R. Z. Sayyed, "Microbial surfactants and their significance in agriculture," in Plant Growth Promoting Rhizobacteria (PGPR): Prospects for Sustainable Agriculture, pp. 205-215, Springer, Manhattan, NY, USA, 2019.

[82] M. Serdaroğlu, B. Öztürk, and A. Kara, "An overview of food emulsions: description, classification and recent potential applications," Turkish Journal of Agriculture-Food Science and Technology, vol. 3, no. 6, pp. 430-438, 2015.

[83] R. K. Sharma, "Surfactants: basics and versatility in food industries," Pharma, vol. 2, no. 3, pp. 17-29, 2014.

[84] N. Lourith and M. Kanlayavattanakul, "Natural surfactants used in cosmetics: glycolipids," International Journal of Cosmetic Science, vol. 31, no. 4, pp. 255-261, 2009.

[85] C. V. T. Rigueto, M. Rosseto, D. D. C. Krein et al., "Alternative uses for tannery wastes: a review of environmental, sustainability, and science," Journal of Leather Science and Engineering, vol. 2, no. 1, pp. 1-20, 2020.

[86] S. Ali, M. Rizwan, A. Waqas et al., "Fulvic acid prevents chromium-induced morphological, photosynthetic, and oxidative alterations in wheat irrigated with tannery waste water," Journal of Plant Growth Regulation, vol. 37, no. 4, pp. 1357-1367, 2018.

[87] A. Zemleduch-Barylska and G. Lorenc-Plucińska, "Populus $\times$ canescens grown on Cr-rich tannery waste: comparison of leaf and root biochemical and proteomic responses," Plant Physiology and Biochemistry, vol. 90, pp. 1-13, 2015.

[88] F. Benlboukht, L. El Fels, R. Bouamri, S. Amir, and M. Hafidi, "Assessment of fulvic acid-like fractions during tannery waste composting," Compost Science \& Utilization, vol. 24, no. 3, pp. 208-218, 2016. 